Review Articles

\title{
The Milieu Interieur and the Islets of Langerhans ${ }^{*}$
}

\author{
R. H. Unger \\ Veterans Administration Medical Center and The University of Texas Health Science Center at Dallas, Dallas, Texas, USA
}

The mid-nineteenth century of Claude Bernard was a time of substantial cultural, technical and scientific achievement in the midst of social upheaval and international conflict. During the 65 years of Bernard's life, France experienced four revolutions and four wars, while producing Balzac, Flaubert, Hugo, de Maupassant, Rodin, Renoir and Cézanne. The Suez Canal had been opened, the telegraph and the railway were in full use throughout the Western world, and the age of technology had begun. But perhaps the greatest glory of the mid-nineteenth century was its science. This was the period when Charles Darwin formulated the doctrine of evolution, Gregor Mendel perceived the laws of heredity, Louis Pasteur laid the foundations of microbiology and modern medicine, and Claude Bernard created experimental medicine and physiology. In short it was the dawn of modern medical science.

The most important conceptual contribution of Claude Bernard was that the constancy of the "milieu interieur" was a condition for the "free life" on this planet, with its inconstant and often inhospitable external milieu. The most important investigative contribution of Bernard was the discovery of a glucoregulatory system that maintains the constancy of glucose in the milieu interieur. This review will focus on both contributions - glucose constancy and the glucoregulatory system that maintains it. The teleology of glucose constancy, the physiology of the glucoregulatory system, that is the insulin-glucagon relationships, the signals that control the insulinglucagon relationship, and, finally, the pathophysiology of glucoregulation in diabetes will be dealt with in turn. Initially, however, the glucoregulatory system as Bernard himself might have viewed it will be examined.

* Claude Bernard Lecture delivered to the European Association for the Study of Diabetes, Athens, September 1980

\section{The 1853 Bernard Model of Glucoregulation}

On March 17, 1853, before the Faculty of Science of Paris, Bernard gave his zoology dissertation entitled "Recherches sur une nouvelle fonction du foie, consideré comme organe producteur de matière sucrée chez l'homme et les animaux" [1]. He introduced the then heretical idea that animals, like plants, could synthesize glucose, and, indeed, that continuous production of glucose by the liver was a characteristic of mammalian life. "Sugar," he said, "is poured by the liver into the blood, and, just like sugar of alimentary origin, must be constantly assimilated and converted into other products." With that sentence he had introduced the concept of glucose flux and turnover. Bernard might indeed have sketched his concept of the system of glucoregulation in the manner of Figure 1. The "milieu interieur", or extracellular space, might have been depicted as a box. He recognized that the glucose constancy within the space is

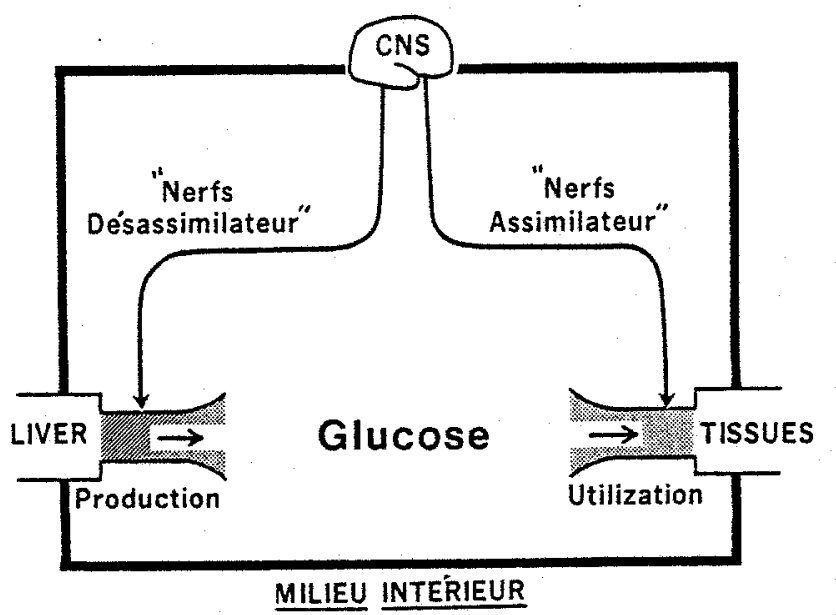

Fig. 1. Schematization based on Claude Bernard's concept of glucoregulation 


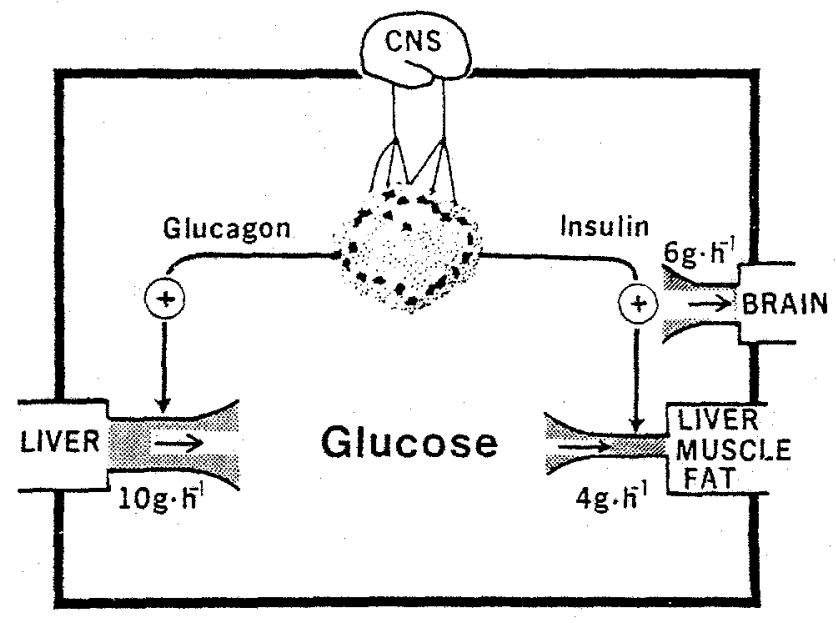

MILIEU INTERIEUR

Fig. 2. A modern schematic model of the glucoregulatory system based on current concepts showing the equality of hepatic glucose production and glucose utilization by the brain and insulin-sensitive tissues in the basal state

maintained through equality of glucose flowing in from the liver or gut and flowing out to tissues. Because of his piqûre experiments five years earlier [2] he was convinced that glucose flux rates were regulated by the central nervous system through a balance of opposing forces: "nerfs desassimilateurs", that stimulate hepatic glucose production, and "nerfs assimilateurs" that stimulate glucose uptake.

\section{Model of Glucoregulation}

Let us now compare this Bernardian model with an updated 1980 model of the glucoregulatory system incorporating information accumulated during the intervening 127 years (Fig. 2). There are modifications but, remarkably, the basic design remains relatively intact. The pancreatectomy experiments of Minkowski in 1889 [3], 40 years after Bernard's piqûre experiments and 11 years after his death, required a relocation of the controls of glucoregulation from the central nervous system to the pancreatic islets. During the current century glucagon and insulin have replaced, respectively, the "nerfs desassimilateurs" and "assimilateurs". Ironically, however, ever since the Pearse hypothesis (see [4] for. review), the islets have seemed increasingly like specialized ganglionic extensions of the central nerv-. ous system, all of their four known secretory products having been identified in the central nervous system proper [5-7]. Clearly, the brain can control the secretion of all four islet peptides through the adrenergic, cholinergic and perhaps peptidergic pathways as elucidated by the groups of Bloom [8], Porte [9], Frohman [10] and others. Perhaps Bernard's 1853 choice of the central nervous system as the site of the control over glucoregulation may ultimately be vind: cated.

\section{Teleology of Glucose Constancy}

Bernard was struck by the constancy of the glucose levels in the dog, irrespective of whether it was in a postprandial or a fasting state. Similarly, in normal humans there is a remarkable constancy of the glucose profile of normal humans [11], which remains between 60 and $180 \mathrm{mg} / \mathrm{dl}(3.3$ to $10 \mathrm{mmol} / \mathrm{l})$ irrespective of the rate of glucose intake or utilization. Today we think we understand the teleology of this glucose constancy, a question left unanswered by Bernard. The normal function of the human brain requires approximately $6 \mathrm{~g}$ of glucose per hour. Evolutionary success requires presumably a foolproof guarantee of these fuel requirements of the central nervous system both in time of tranquility and during survival crises, such as fight, flight, famine, or injury. The fact that $6 \mathrm{~g}$ of glucose per hour can be delivered to the brain only if the arterial glucose concentration is maintained above $50 \mathrm{mg} / \mathrm{dl}$ may explain why this level is so staunchly defended. The equally vigorous defense against hyperglycaemia may reflect the fact that hyperglycaemia interferes with normal control of glycosylation, a carefully regulated posttranslational process by which certain proteins derive their special structural and functional characteristics [12]. Excessive glycosylation caused by chronic hyperglycaemia can modify the structure and functions of proteins, sometimes with adverse consequences, as Spiro has discussed in a previous Claude Bernard Lecture [13]. Thus, Cerami and his colleagues incubated crystallin lens protein with high concentrations of glucose or glucose-6-phosphate [14]. After 28 days they observed the development of opalescence and other changes similar to those of in vivo cataract development. They suggest that nonenzymatic glycosylation of lens proteins promotes the formation of large protein aggregates through disul. fide crosslinkages, and that these aggregates scatte light. Thus, simple exposure of a protein to a higt glucose concentration seems to have produced the first diabetic complication in vitro; if so, it is indeed : remarkable achievement. It would be naive to ascribe all of the complex tissue damage that can develop ir chronically hyperglycaemic patients to a single chemical abnormality, when so many other potentiall: deleterious abnormalities coexist. Nevertheless, post translational modification of proteins by glucose doe: 

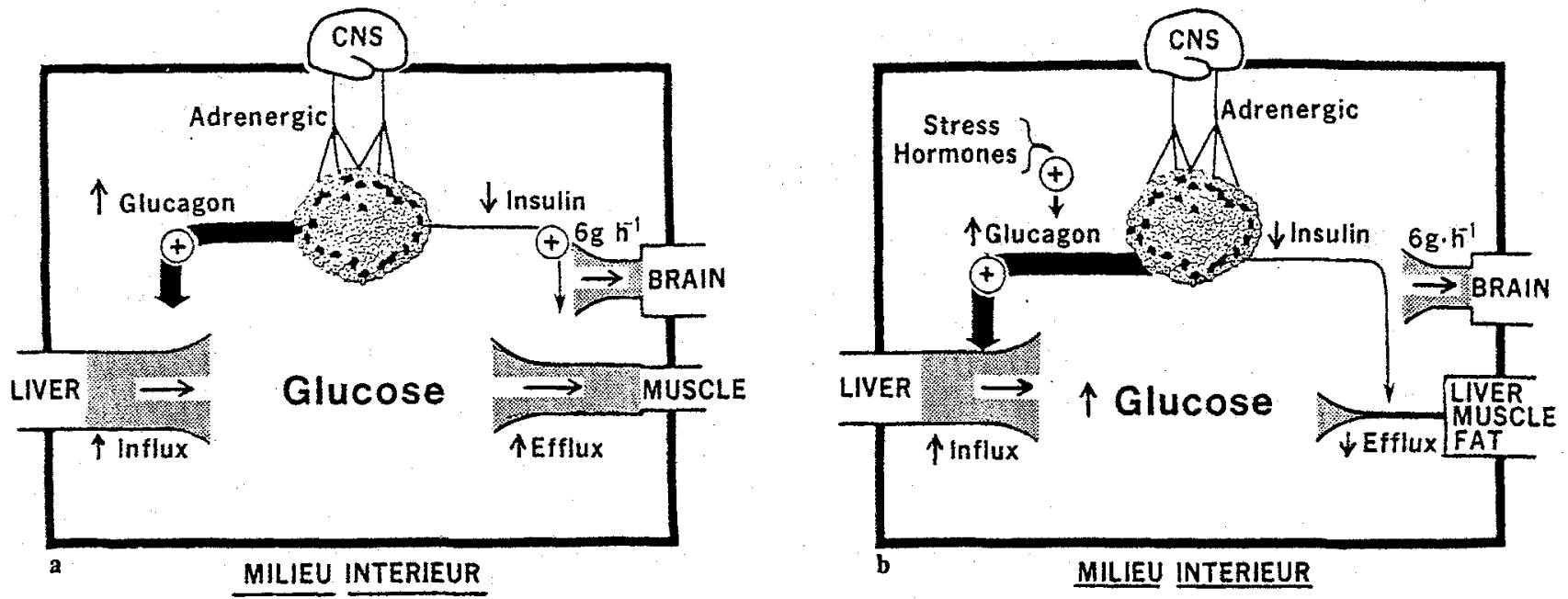

Fig. 3. a Fight and flight: Schematization of glucoregulation during fight and flight situations in which sudden and marked increase in glucose utilization by intense muscular effort drains glucose from the milieu interieur. Unless it is promptly replaced by increased hepatic glucose production, hypoglycaemia would occur. However, adrenergic control over the islets stimulates glucagon secretion and enhanced hepatic glucose production, while it suppresses insulin release to minimize glucose outflow to tissues other than brain and exercising muscle. Thus, normoglycaemia and cerebral glucose delivery is preserved despite the massive increase in glucose efflux. b Severe injury: During injury cerebral hypoperfusion resulting from hypovolaemic shock compromises the delivery of glucose to the brain. Stress hyperglycaemia a compensatory response, is produced through adrenergic enhancement of glucagon secretion, to stimulate glucose production, anc inhibition of insulin secretion to curtail glucose efflux into insulin-sensitive tissues, liver, muscle and fat. Thus, all endogenousiy producec glucose is conserved for utilization by the brain and other insulin-independent tissues, and "fixity" of the internal milieu sacrificec temporarily during the acute threat to life

provide both a unifying biochemical link between hyperglycaemia [15] and diabetic tissue damage and an attractive explanation for nature's rigorous efforts to keep the glucose concentration below $200 \mathrm{mg} / \mathrm{dl}$. Indeed, a study in Pima Indians [16] indicates that $200 \mathrm{mg} / \mathrm{dl}$ is precisely the level above which a quantitative relationship between postprandial hyperglycaemia and the incidence of retinopathy appears within 6 years.

Thus, it seems that the rationale for the avoidance of glucose lows and highs may be, respectively, inadequate cerebral fuel delivery and overglycosylation of proteins with deleterious consequences.

\section{Physiological Mechanisms of Glucose Constancy}

Let us now consider mechanisms by which a large amount of glucose can move into or out of the milieu interieur without violating these concentration boundaries under widely varying circumstances, such as the basal state, a survival crisis, and during a meal. Constancy of concentration during marked inconstancy of flux can be maintained only by means of a "push-pull" system similar to that envisioned by Bernard - one that can always maintain an equality of the glucose that enters and the glucose that leaves the milieu, irrespective of the magnitude of a change in either. This equilibrium is achieved through the coor- dinated antagonism of glucagon and insulin $[17,18]$, which control the rates, respectively, of glucose influx and glucose efflux.

\section{The Basal State (Fig. 2)}

About $75 \%$ of hepatic glucose production in the basal state is glucagon-mediated [19]. Seventy five percent of the $10 \mathrm{~g}$ of glucose produced hourly by the human liver is more than enough for the hourly glucose requirement ( $6 \mathrm{~g}$ per hour) of the human brain. This suggests a vital relationship between the A-cells and the brain. Vidnes and Oyasaeter have reportec the only known case of glucagon deficiency, an infan with intractable and ultimately fatal hypoglycaemia. who responded for several weeks to glucagor replacement [20]. One can wonder, therefore, it glucagon-mediated basal glucose production may no be essential for life, at least in the perinatal period.

\section{In Survival Crises (Fight and Flight, Injury, Famine,}

Survival requires that cerebral glucose needs be me in time of crisis, as well as at rest. Situations of figh and flight constitute two common survival crise: (Fig. 3a). In both, instant and intense muscula: response greatly augments glucose utilization ane would quickly cause hypoglycaemia were glucose no replaced as fast as it is used. In such circumstance: 


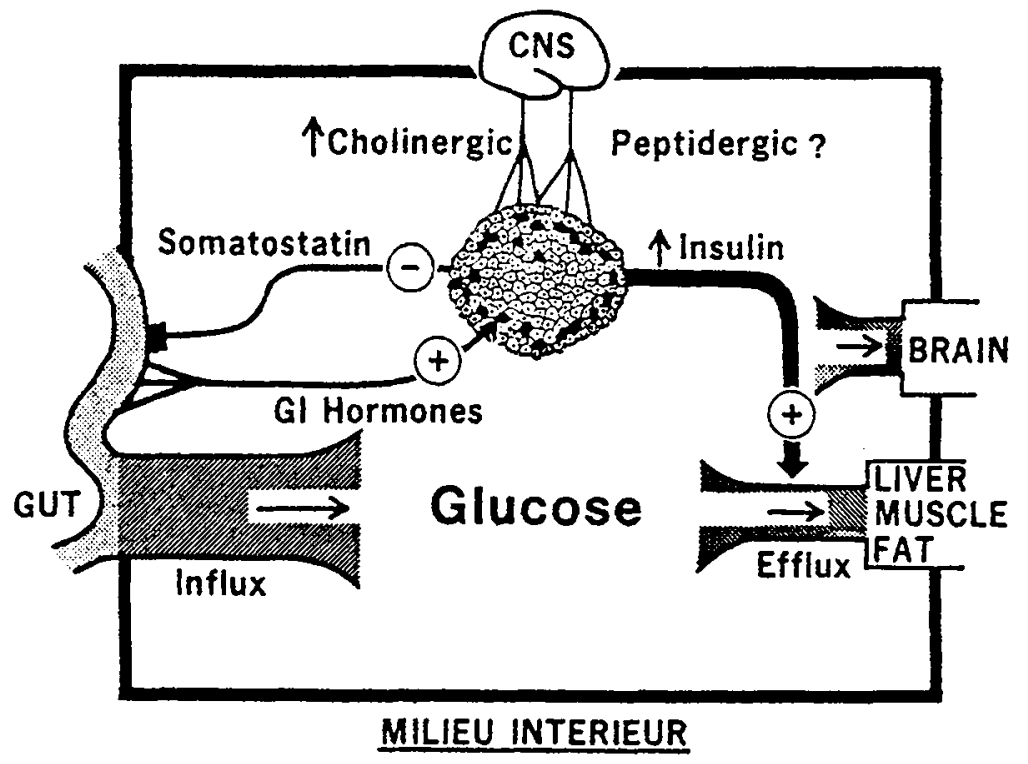

Fig. 4. Glucoregulation during meals: Glucose influx from the gut is preceded by an appropriately timed and quantitated insulin release mediated by $G I$ hormones and vagal and perhaps peptidergic signals to the islets. This anticipatory response of insulin permits glucose uptake by insulin responsive tissues to proceed almost as rapidly as glucose absorption, an "open-loop" type of insulin delivery arrangement. At the same time, somatostatin secretion may serve to coordinate nutrient influx from the gut with insulin-controlled glucose efflux from the circulation, providing further assurance against perturbation of nutrient concentrations clearly the central nervous system, in responding to the crisis, instantly assumes complete control of islet function [21-24]. Adrenergically stimulated glucagon secretion increases glucose production so as to replace precisely the extra glucose used by muscle, while simultaneous adrenergic suppression of insulin secretion serves, to prevent the endogenously produced glucose from entering the insulin-responsive tissues, such as fat and liver, in which it is not important in such circumstances.

After serious injury (Fig. 3b), hypovolaemic shock will reduce cerebral blood flow and, thereby, glucose delivery will be diminished. Survival may depend on the ability of the glucoregulatory system to deliver glucose to a hypoperfused brain. This can be accomplished only by a rise in arterial glucose levels. Thus, if arterial glucose concentration is doubled, a $50 \%$ decline in cerebral blood flow can be tolerated without a net reduction in glucose delivery to the brain. In this manner, stress-induced hyperglycaemia, the endogenous equivalent of a glucose infusion, may help to prolong life until the crisis has passed. Once again the central nervous system, in response to the danger, takes full command of islet function [25-27]. Adrenergic stimulation of glucagon and suppression of insulin secretion stimulate glucose production by the liver in a setting in which glucose efflux to tissues other than central nervous system is minimized, thus preventing glucose wastage in the tissues for which it is not essential. These adrenergic signals can maintain stress hyperglycaemia for as long as is desirable by overriding the glucagon-suppressing and insulin-stimulating effects of the hyperglycaemia and thus preventing its self-correction through the feedback controls that operate in the unstressed state. In addition to direct neural control over the islets, the stress hormones, growth hormone [28], $\beta$-endorphin [29] and cortisol [30] enhance glucagon secretion. Cortisol also potentiates the hepatic actions of glucagon [17].

Finally, in starvation, when protein conservation becomes critical to survival, the same high glucagonlow insulin mixture [31] serves the needs of the brain by mobilizing fatty acids (see 32 for review). This reduces glucose utilization through the Randle glucose-fatty acid cycle and yields substrate for ketogenesis, a glucagon-mediated process [33] that provides a substitute fuel for the brain. Once again, through these simple changes in the glucagon-insulin mixture, the complex fuel needs of the brain and other tissues are adjusted with remarkable precision to cope with environmental changes.

\section{In the Fed State (The "Enteroinsular System")}

If the defense against hypoglycaemia depends heavily on the glucagon response, the defense against postprandial hyperglycaemia depends on appropriate timing and quantity of the insulin response to each meal. All nutrients, including glucose, are very weak stimuli of insulin secretion, especially when their concentration is in the low normal range. Avoidance of a high postprandial nutrient level, therefore, requires an "open loop" type of insulin delivery system capable of preventing as well as reacting to and correcting such perturbations (Fig. 4). The B-cell must, therefore, anticipate, rather than simply respond to, an inflowing glucose tide. The term "enteroinsular axis" has been applied to meal-induced humoral signals to the islets secreted by the gastrointestinal tract [34]. 


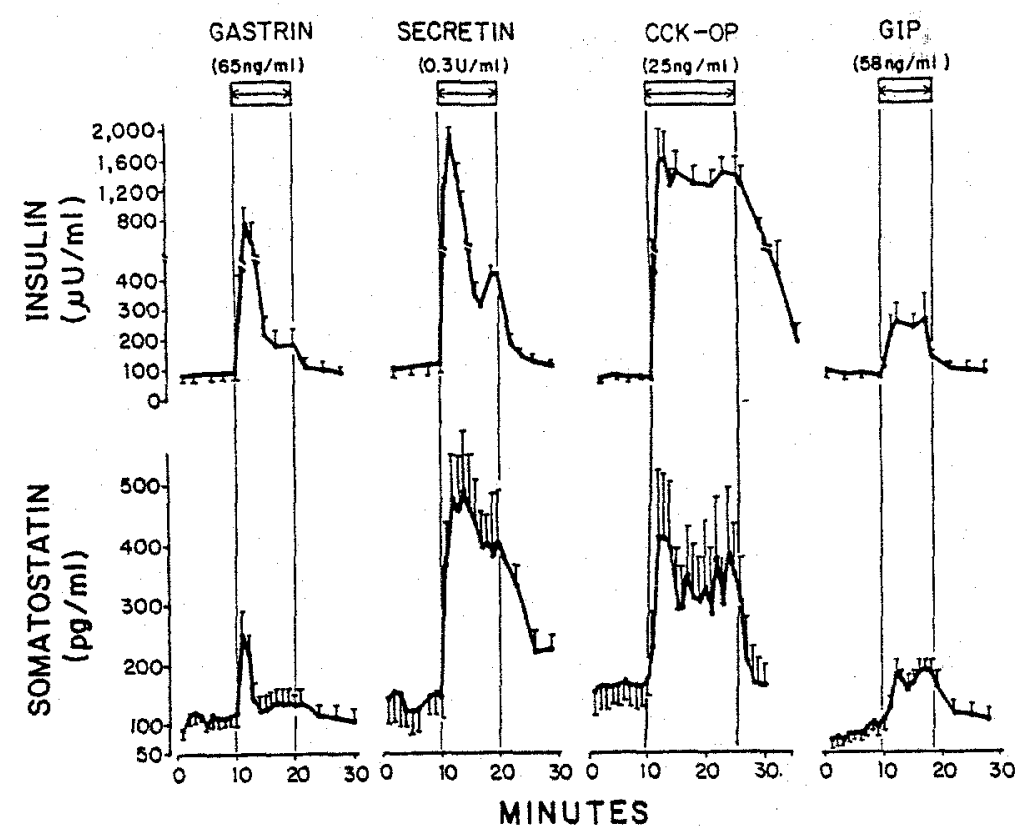

Fig. 5. Similarity of patterns of somatostatin and insulin release by the isolated perfused canine pancreas in response to four gastrointestinal hormones. (Reprinted courtesy of J Clin Invest [39])

Such signals, in particular GIP, the importance of which has been emphasized by several workers [35-37], together with cholinergic [38] and perhaps peptidergic signals, orchestrate an anticipatory pattern of insulin release that promotes uptake of the inflowing substrates by these insulin-sensitive tissues almost as fast as they enter. These signals, which were previously assigned a secondary role in the prandial insulin response to nutrients, may well provide the primary stimulus, at least in the early phase response. However, if nutrient concentrations approach or exceed the upper limits of normal, then they themselves begin to elicit a self-correcting "closed loop" type of insulin response.

Gut hormones also stimulate somatostatin release in parallel with that of insulin [39], and, it has been postulated that somatostatin, like insulin, may be involved in the maintenance of nutrient constancy after meals [40]. Somatostatin restrains the secretion of the gut hormones $[41-48]$ that stimulate it, thus suggesting a complete positive-negative feedback circuit between gut and islets (Fig. 4) [49]. This action of somatostatin and its other direct inhibitory actions on a broad range of digestive functions $[44-48,50$, 51 , provide a means by which the islets can control the rate at which ingested nutrients cross from the external environment of the gut lumen into the internal milieu of the body $[52,53]$. The striking parallelism between somatostatin and insulin secretion [39] suggests a coupling between D- and B-cells (Fig. 5); such coupling could minimize postprandial perturbation of nutrient concentrations by coordinating the influx of ingested nutrients with their insulin-mediated efflux.

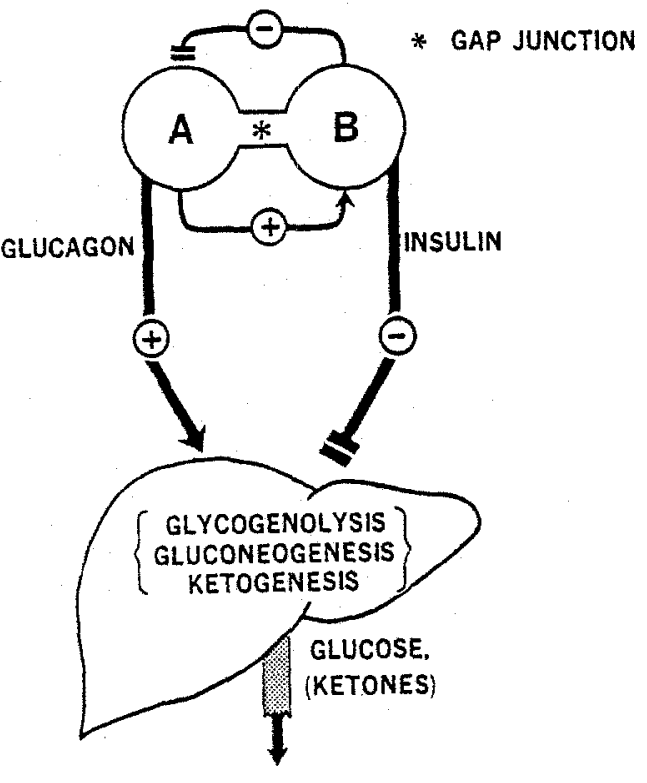

Fig. 6. Postulated mechanisms of "functional coupling" of A- and $B$-cells via paracrine and gap junctional connections. The stimulatory effects of glucagon on the B-cells and the inhibitory effect of insulin on the A-cell provides a short "paracrine" loop by which simultaneous responses of the two hormones might protect against perturbations of nutrient concentration that would result from unilateral action of one of them

\section{The Signals that Control Insulin: Glucagon Relationships}

Is the remarkable functional coordination of the components of the islets required to maintain glucose constancy derived entirely from signals arising from outside the islets, i. e., the neurotransmitters and hor- 


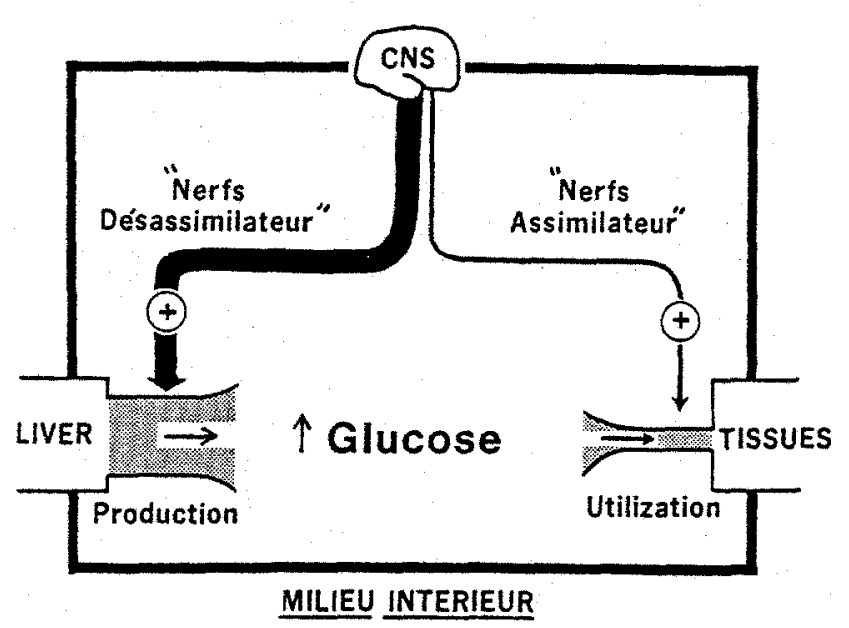

Fig. 7. Schematization of Bernard's concept of the pathophysiology of diabetes showing preponderance of "désassimilation"

Table 1. Metabolic consequences of the bihormonal abnormality

\begin{tabular}{ll}
\hline Insulin lack & Glucagon excess \\
\hline$\downarrow$ Glucose utilization & $\uparrow$ Hepatic glycogenolysis \\
$\uparrow$ Proteolysis & $\uparrow$ Hepatic gluconeogenesis \\
$\uparrow$ Lipolysis & $\uparrow$ Ketogenesis \\
\hline
\end{tabular}

mones already mentioned in the preceding section? $\mathrm{Or}$, in addition, is an exchange of signals between the islet cells themselves required for the production of the appropriately titrated secretion mixtures produced by the normal islets? Signals between islet cells could be transmitted by two routes, first, across intervening interstitial spaces, the paracrine route first suggested by Feyrter [54], and/or, second, through their gap junctions [55].

\section{Paracrine Signals}

The nonrandom distribution of the islet cells creates a heterocellular region of contiguity between A-cells, $D$-cells and the outer tier of B-cells in which paracrine pathways would be possible $[56,57]$. Additionally, the fact that glucagon stimulates both B- [58] and D-cells [59], insulin inhibits A-cells [60] and somatostatin inhibits both A- [61] and B-cells [62] provides the functional basis for the existence of such a system. There is, for example, powerful evidence that A- and B-cells may modulate each others' secretory activity, through the positive-negative feedback arrangements described by Samols 15 years ago [58, 60] (Fig. 6). A short paracrine feedback loop could regulate the timing and composition of the insulin and glucagon mixture and thus titrate more

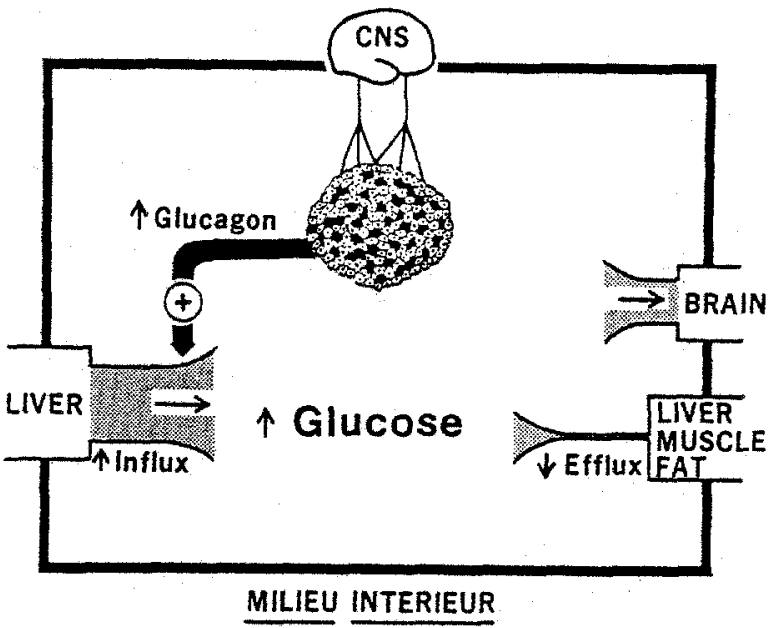

Fig. 8. Schematization of a current concept of the pathogenesis of diabetes showing the bihormonal abnormality hypothesis

precisely their antagonist actions on hepatic glycogenolysis, gluconeogenesis and ketogenesis. Thus, the glucagon released during a protein meal can shift glucose from the liver into the peripheral tissues without an important increase in the blood glucose level because insulin secretion is stimulated concurrently, rather than after glycogenolysis. Conversely, during a. glucose load insulin can directly suppress glucagon secretion while it is opposing the actions of glucagon on the liver; there is indeed impressive, if indirect, evidence that glucose-induced suppression of glucagon secretion is entirely mediated by insulin. In the absence of insulin, the A-cell behaves as if it has no real glucose sensor of its own, or, as Buchanan first showed [63], it responds paradoxically to hyperglycaemia.

\section{Gap Junction Signals}

A second possible route of islet cell-to-islet cell information exchange is via their gap junctions, first described by Orci et al. [64]. Meda et al. have shown that cyclic nucleotides can pass from one islet cell to another without entering the islet interstitium [65]. Ions and other small molecules may do the same. Thus, gap junctions may link all the cellular components of the islets to form a functional syncytium, but their precise role is still unidentified.

\section{Pathophysiology in Diabetes}

The same model used to examine the normal glucoregulatory systems can be used to examine the pathophysiology of the diabetic state. In $1859 \mathrm{Ber}-$ 
nard aptly summarized the pathophysiology of diabetes in three brief sentences: "In diabetes the liver oversecretes. The matter changed there to sugar cannot be transformed into a more complex product. Desassimilation," as he referred to glycogenolysis and other catabolic processes, "has become preponderant" [66] (Fig. 7). Bernard's emphasis on the role of "desassimilation" or glucose overproduction in diabetic hyperglycaemia was disputed for almost a century, before its rediscovery and acceptance in relatively recent times. Today, it is recognized that overproduction of glucose relative to its utilization, is the cause of endogenous hyperglycaemia.

Whereas Bernard attributed the disequilibrium between glucose influx and efflux to a preponderance of the "nerfs desassimilateurs" relative to the "nerfs assimilateurs", we, at least some of us, attribute it to a preponderance of glucagon [67-72] action relative to insulin action, irrespective of the absolute concentration of either hormone in $\mathrm{pg} / \mathrm{ml}$ [72-74] (Fig. 8). In Type I (insulin dependent) diabetes the relative hyperglucagonaemia is secondary to an absence or paucity of B-cells. The loss of the restraining influence of coupled insulin secretion upon the A-cells results in a bihormonal abnormality $[73,74]$, i. e., a combination of insulin lack and rellative or absolute hyperglucagonaemia (Table 1). Both abnormalities contribute to the metabolic syndrome of uncontrolled diabetes. Insulin lack is to blame for the extrahepatic abnormalities: reduced glucose utilization by the insulin sensitive tissues, and increased proteolysis and lipolysis, i. e., release of amino acids from muscle and fatty acids from adipocytes. Hyperglucagonaemia (or biologically glucagon-like substances other than glucagon) appears to be essential for the hepatic abnormalities of diabetes: increased glycogenolysis, gluconeogenesis and ketogenesis (see [74] for review). The insulin lack in and of itself plays no direct role in this overproduction of glucose and ketones, other than to allow the unrestrained secretion and action of glucagon and/or epinephrine [75]. McGarry and Foster (personal communication) have convincing new in vitro evidence that insulin's only action of the liver is to oppose glucagon, so that in the absence of glucagon, the presence or absence of insulin is irrelevant with respect to hepatic fuel production. This supports the earlier in vivo work by Gerich in man [76], Cherrington et al. in dogs [77] and ourselves in both dogs [78] and man $[79,80]$. As shown in Figure 9, when both insulin and glucagon are essentially zero, as during a somatostatin infusion in an insulin-deprived Type I diabetic, massive hepatic overproduction of fuels does not occur; glucose levels remain well below $180 \mathrm{mg} / \mathrm{dl}$ and there is no glycosuria or ketonuria.

\begin{tabular}{c|c|c|c|c|}
\hline $\begin{array}{c}\text { INSULIN : } \\
\mu U / m I\end{array}$ & 0 & 25 & 25 & 25 \\
\hline $\begin{array}{c}\text { GLUCAGON : } \\
\text { pg/mI }\end{array}$ & 0 & $\sim 100$ & $\sim 300$ & $\sim 600$ \\
\hline $\begin{array}{c}\text { GLYCEMIA } \\
\text { mg/dI }\end{array}$ & $<180$ & 200 & 260 & 293 \\
\hline $\begin{array}{c}\text { URINE } \\
\text { GLUCOSE 100- } \\
\text { g/24h } 50-\end{array}$ & 40 & 80 & 150 \\
\hline $\begin{array}{c}\text { KETONES 2000- } \\
\text { MM/24h 1000- }\end{array}$ & 480 & 1800 & 2000 \\
\hline
\end{tabular}

Fig. 9. A resume of clinical data demonstrating the roles of insulin and glucagon in hepatic fuel overproduction. When both insulin and glucagon are absent the massive hyperglycaemia and hyperketonaemia observed in the presence of glucagon does not occur. In patients in whom insulin was clamped at approximately $25 \mathrm{uU} /$ $\mathrm{ml}$ for three days, hyperglycaemia, glycosuria and ketonuria increased progressively as glucagon levels rose as the result of a constant low-dose glucagon infusion. Thus in the absence of glucagon deficiency of insulin does not result in massive overproduction of fuels by the liver. Data adapted from Gerich et al. [76] and from Raskin and Unger [80]

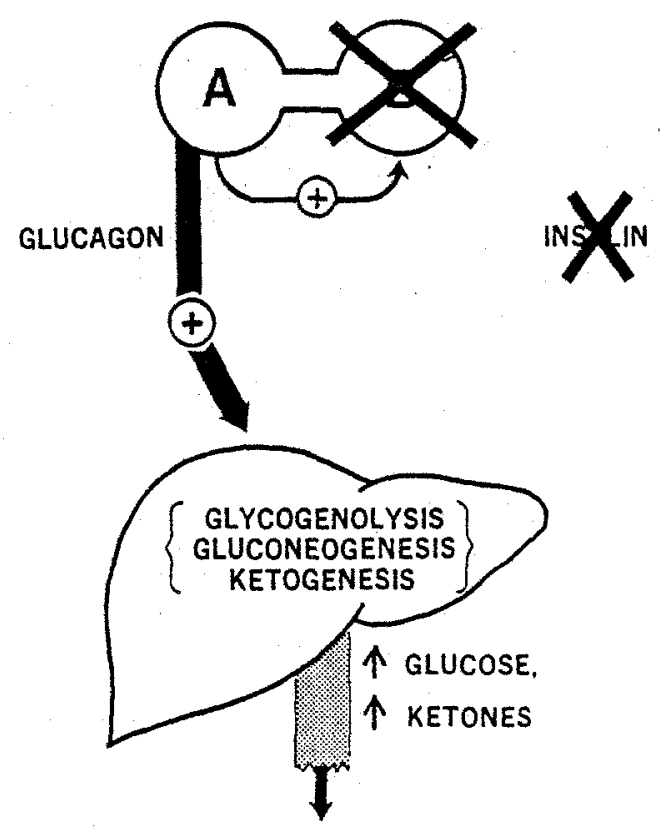

Fig. 10. The absence of a sufficient number of B-cells eliminates the normal inhibitory effect of insulin on the A-cell (see Figure 6) and both paracrine and gap junctional coupling with B-cells is lacking. The resulting hyperglucagonaemia stimulates glucose and ketone production in the liver without opposition from insulin. The resulting hyperglycaemia can neither be corrected by compensatory insulin-mediated uptake in tissues nor reduced by inhibition of glucagon secretion, since this too is an insulin-requiring process 
On the other hand, in such diabetics even with insulin levels clamped for $24 \mathrm{~h}$ at the normal basal level of $25 \mu \mathrm{U} / \mathrm{ml}$, small progressive increments in glucagon produced by glucagon infusion increase hepatic glucose and ketone body production, as reflected by an increase in hyperglycaemia level and a massive increase in glycosuria and ketonuria. These results illustrate the importance of the normal coupling between A- and B-cells. When an increase in glucagon is not accompanied by the normal, appropriately timed increase in insulin (Fig. 10) that occurs when normal B-cells are linked functionally to A-cells, then a rise in glucagon will cause hyperglycaemia. In the absence of a rise in insulin, this hyperglycaemia cannot be quickly taken up in peripheral tissues and cannot suppress glucagon. Thus, the all-important glucoregulatory feedback loop is severed.

However, appropriately timed and quantitated replacement of insulin via the open loop system pioneered by Pickup et al. [81], corrects both abnormalities, the insulin lack and the relative hyperglucagonaemia [82]. The glucose profile becomes normal. Thus, the bihormonal defect has responded to unihormonal replacement with insulin.

The bihormonal defect is also present in noninsulin dependent diabetes, but here its mechanism must be different. In contrast to the ease with which all the A-cell abnormalities of insulin-dependent diabetes can be corrected with insulin, in most noninsulin dependent diabetics insulin fails to correct the exaggerated glucagon secretion $[83,84]$, although it reduces the basal glucagon levels [85]. In these patients, of course, there is no absolute deficiency of insulin; indeed, it is often abundant. Conceivably in some cases of non-insulin dependent diabetes there is insulin resistance in both A-cells and B-cells to the inhibitory effects of insulin on both insulin and glucagon secretion with resulting hypersecretion of both hormones. Alternatively, a relative local deficiency of somatostatin as described in ob/ob mice [86] could be an aetiologic factor in certain cases. These and other hypotheses can be tested in the second postBernardian century just beginning.

\section{A Look at the Second Post-Bernardian Century}

I have attempted to provide a panoramic view of concepts of the glucoregulatory system, as they have evolved from the time of Claude Bernard to the end of the first century after his death.

The full implications of the concepts of Claude Bernard and those of Charles Darwin for medical science have yet to be fully recognized or applied, even as we enter the second post-Bernardian century in which astounding progress in medicine is occurring at other levels. Claude Bernard had predicted "... that in a hundred years physiology would enable man to make laws for organisms and carry out human creation in competition with the Creator himself," [87], but it is not clear if he recognized the enormous potential power for human health of his own simple concept of fixity of the internal milieu. He saw it as essential for the "free life", but did not to my knowledge, equate it with health in the medical sense. Rather, it was Walter Cannon, who first emphasized that "health ... depends on what are called homeostatic processes ..." Nor did Bernard seem to see a link between his concept of fixity of the milieu interieur and the ideas of Darwin. According to both Virtanen [88] and Olmstead [89], Bernard's attitude toward evolution and Darwinism was noncommittal or even adverse - he regarded it as "speculative and of no use for the physician." He had little interest in hypotheses that did not lead to experimental verification.

Yet, the combined ideas expressed by these two men may hold more hope for future health of man through disease prevention than any powerful new therapy of the future designed to reverse the endstage biologic catastrophes that fill our hospital beds today. Consider the following premises: first, cells have adapted over millions of years in an optimally fixed medium and their health and species survival constitute evidence of their compatability with their environment. Second, any modification to the milieu from that in which a cell line has evolved will place them at risk, that may be expressed as malfunction, disease or death. Third, most modifications of the internal milieu today are induced by man, rather than by nature; therefore, theoretically they are preventable.

A chronology of man's increasing ability to modify both his internal and external environments is given in Table 2 in relation to his principal health problems. It should be noted that this depressing list of man-made pathogenic environmental modifications includes two items, the last two on the list, of specific interest to the diabetologist. These are obesity and its relationship to Type II (non-insulin dependent) diabetes, and the introduction of insulin used in a way that prevents the death of Type I diabetics but permits chronic metabolic derangements. Like every other environmental modification on the list, both of these are preventable. But, man's ability to modify his environment appears to be infinitely more powerful than his will to restore it to its original constancy Indeed, after 40 years of debate, diabetologists dc not yet agree that efforts to restore the milieu tc normal are even warranted. 
Table 2. Chronology of man-made pathogenic modifications of his enviromment

\begin{tabular}{|c|c|c|c|}
\hline Date & Event & Change & Disease or risk \\
\hline 10000 B.C. & Domestication of cattle & $\begin{array}{l}\text { High consumption of meat \& dairy } \\
\text { products. }\end{array}$ & Atherosclerosis \\
\hline 4000 B. C. & Fermentation of grapes & $\begin{array}{l}\text { Alcohol ingestion \& aldehyde-pro- } \\
\text { tein adduct formation (?) }\end{array}$ & $\begin{array}{l}\text { Cirrhosis; pancreatitis; fetal alcohol } \\
\text { syndrome; CNS disorders, etc. }\end{array}$ \\
\hline $2700 \mathrm{~B} . \mathrm{C}$. & $\begin{array}{l}\text { Herbal medicine begins; later } \mathrm{Nei} \\
\text { Ching introduces opium, ephedrine, } \\
\mathrm{NaSO}_{4}\end{array}$ & Drugs are prescribed & Drug-induced diseases of all types \\
\hline 1233 A. D. & Coal mining begins in Newcastle & $\begin{array}{l}\text { Coal leads ultimately to the indus- } \\
\text { trial revolution, urbanization, use of } \\
\text { other fossil fuels, polluof air, water } \\
\text { \& soil by industrial byproducts }\end{array}$ & $\begin{array}{l}\text { Occupational diseases of miners; } \\
\text { ultimately, diseases of general popu- } \\
\text { lation caused by industrial pollution }\end{array}$ \\
\hline 1531 A.D. & $\begin{array}{l}\text { Tobacco is cultivated on a commer- } \\
\text { cial scale by Spanish colonists }\end{array}$ & Smoking begins & $\begin{array}{l}\text { Bronchopulmonary disease and car- } \\
\text { cinomas; increased ASHD }\end{array}$ \\
\hline 1898 A.D. & Radium is isolated by the Curies & Nuclear age begins & Neoplasia; mutations \\
\hline 1920 A.D. & $\begin{array}{l}\text { Inversion of the relationship of } \\
\text { income to physical work creates a } \\
\text { sedentary lifestyle; cheap, overly } \\
\text { accessible fast foods }\end{array}$ & $\begin{array}{l}\text { Decline in the caloric cost of food, } \\
\text { i. e. the previously balanced physical } \\
\text { work/food ratio }\end{array}$ & $\begin{array}{l}\text { Obesity; increased arteriosclerotic } \\
\text { heart disease; diabetes (Type II) }\end{array}$ \\
\hline 1923 A. D. & Insulin made commercially available & $\begin{array}{l}\text { Type I diabetics now can survive, but } \\
\text { chronic hyperglycaemia, overgly- } \\
\text { cosylates proteins }\end{array}$ & Diabetic vasculopathy \\
\hline
\end{tabular}

Perhaps these physiological and pathophysiological insights, coupled with new methods for maintaining the metabolic constancy of the diabetic milieu interviews, will persuade clinicians to apply the Bernardian concept of environmental fixity in an attempt to prevent post-translational modifications in their diabetic patients:

Acknowledgements. This work was supported by VA Institutional Research Support Grant 549-8000-01; NIH Grant AM02700-16 and Contract N01-AM-62219; CIBA-Geigy Corp., Summit, $\mathrm{NJ}$; Eli Lilly Co., Indianapolis, Ind.; and The Salk Institute - Texas Research Foundation, Houston, Tx.

The author thanks the following persons for their technical assistance: Ms. Anne Eisentraut, Ms. Virginia Harris, Ms. Kay McCorkle, Ms. Loretta Clendenen, Ms. Helen Gibson, Ms. Mary Lintner, Ms. Lovie Peace and Mr. Daniel Sandlin; for secretarial assistance, Mrs. Susan Kennedy. The author also thanks Drs. Donald W. Seldin and J. Denis McGarry of Dallas for advice and Drs. Anthony Cerami and Charles Peterson for access to their recent findings, some of which were still unpublished. Finally the author acknowledges with gratitude the contributions of all of the pre- and post-doctoral Fellows with wuhom he has had the priviledge of collaboration.

\section{References}

1. Bernard C (1853) Recherches sur une nouvelle fonction du foie, consideré comme l'organe producteur de matière sucrée chez lhomme et les animaux. Martinet, Paris

2. Bernard C: Extraits Proces-Verbaux Soc Philomatique, $p 49$

3. von Mering J, Minkowski O (1889) Arch Exp Pathol Pharmacol 26:371
4. Pearse AGE, Takor TT (1979) Embryology of the diffuse neuroendocrine system and its relationship to the common peptides. Fed Proc 38: 2288-2294

5. Havrankova J, Schmechel D, Roth J, Brownstein M (1978) Identification of insulin in rat brain. Proc Natl Acad Sci USA . 75: 5737-5741

6. Conlon JM, Samson WS, Dobbs RE, Orci L, Unger RH (1979) Glucagon-like polypeptides in canine, brain. Diabetes 28: 700-702

7. Sundler F, Håkanson R, Alumets J, Walles B (1977) Neuronal localization of pancreatic polypeptide (PP) and vasoactive intestinal peptide (VIP) immunoreactivity in the earthworm (Lumbricus Terrestris). Brain Res Bull 2: $61-65$

8. Edwards AV, Bloom SR (1978) Nervous control of pancreatic hormones. In: Bloom SR (ed) Gut hormones. Churchill Livingstone, Edinburgh London New York, p 394-405

9. Porte D, Graber AL, Kuzuya T, Williams RH (1966) The effect of epinephrine on immunoreactive insulin levels in man. $\mathrm{J}$ Clin Invest $45: 228-236$

10. Frohman LA, Bernardis LL (1971) Effect of hypothalamic stimulation on plasma glucose, insulin and glucagon levels. Am J Physiol 221: 1596-1603

11. Unger RH (1976) Diabetes and the alpha cell (Banting Memorial Lecture). Diabetes 25: 136-151

12. Uy R, Wold E (1977) Posttranslational covalent modification of proteins. Science 198: 890-896

13. Spiro RG (1976) Search for a biochemical basis of diabetic microangiopathy. Diabetologia 12:1-14

14. Stevens VJ, Rouzer CA, Monnier VM, Cerami A (1978) Diabetic cataract formation: Potential role of glycosylation of lens crystallins. Proc Natl Acad Sci USA 75: 2918-2922

15. Cerami A, Stevens VJ, Monnier VM (1979) Role of nonenzymatic glycosylation in the development of the sequelae of diabetes mellitus. Metabolism 28 [Suppl 1]: 431-437

16. Lisse JR, Knowler WC, Pettitt DJ, Bennett PH (1980) Incidence of retinopathy and cardiovascular events as a function of plasma glucose. Diabetes 29 [Suppl 2]: $57 \mathrm{~A}$ 
17. Park CR, Exton JH (1972) Glucagon and the metabolism of glucose. In: Lefebvre PJ, Unger RH (eds) Glucagon: Molecular physiology, clinical and therapeutic implications. Pergamon Press, Oxford, p 77-108

18. Mackrell DJ, Sokal JE (1969) Antagonism between the effects of insulin and glucagon on the isolated liver. Diabetes 18 : $724-732$

19. Cherrington $A D$, Williams PE, Liljenquist JE, Lacy WW (1979) The control of glycogenolysis and gluconeogenesis in vivo by insulin and glucagon. In: Pierluissi J (ed) Endocrine pancreas and diabetes. Excerpta Medica, Amsterdam Oxford, p 172-191

20. Vidnes $J$, Oyasaeter S (1977) Glucagon deficiency causing severe neonatal hypoglycemia in a patient with normal insulin secretion. Pediatr Res 11: 943-949

21. Harvey WD, Faloona GR, Unger RH (1974) The effect of adrenergic blockade on exercise-induced hyperglucagonemia. Endocrinology 94: 1254-1258

22. Vranic M, Kawamori $R$ (1978) Essential roles of insulin and glucagon in regulating glucose fluxes during exercise in dogs: Mechanism of hyperglycemia. Diabetes 28 [Suppl 1]: 45-52

23. Galbo H, Holst JJ, Christensen NJ, Hilsted J (1976) Glucagon and plasma catecholamines during beta receptor blockade in exercising man. J Appl Physiol 40: 855-863

24. Luyckx AS, Pirnay F, Lefebvre PJ (1978) Effect of glucose on plasma glucagon and free fatty acids during prolonged exercise. Eur J Appl Physiol 39: 53-61

25. Lindsey CA, Faloona GR, Unger RH (1975) Plasma glucagon leveis during rapid exsanguination with and without adrenergic blockade. Diabetes 24: 313-319

26. Wilmore DW, Lindsey CA, Moylan JA, Faloona GR, Pruitt BA, Unger RH (1974) Hyperglucagonemia after burns. Lancet. I: $73-75$

27. Lindsey CA, Santeusanio F, Braten J, Faloona. GR, Unger RH (1974) Pancreatic aipha cell function in trauma. JAMA 227: 757-761

28. Tai TY, Pek S (1976) Direct stimulation by growth hormone of glucagon and insulin release from isolated rat pancreas. Endocrinology 99: 669-677

29. Ipp E, Dobbs RE, Unger RH (1978) Morphine and $\beta$-endorphin influence the secretion of the endocrine pancreas. Nature 276: 190-191

30. Marco J, Calle C, Roman D, Diaz-Fierros $M$, Villanueva $M$, Valverde I (1973) Hyperglucagonemia induced by glucocorticoid treatment in man. N Engl J Med 288: 128-131

31. Aguilar-Parada E, Eisentraut M, Unger RH (1969) Effects of starvation on plasma pancreatic glucagon in normal man. Diabetes 18: 717-723

32. Lefebvre $P$ (1972) Glucagon and lipid metabolism. In: Lefebvre PI, Unger RH (eds) Glucagon: Molecular physiology, clinical and therapeutic implications. Pergamon Press, Oxford, p 109-119

33. McGarry JD, Foster DW (1977) Hormonal control of ketogenesis. Arch intern Med 137: 495-501

34. Unger RH, Eisentraut AM (1969) Entero-insular axis. Arch Intern Med 123: 261-266

35. Creutzfeldt W (1979) The incretin concept today. Diabetologia $16: 75-85$

36. Brown JC, Pedersen RA (1977) GI hormones and insulin secretion in endocrinology. Proc $V$ Int Congr Endocrinol. Excerpta Medica, Amsterdam, p 568-570

37. Dupré J, Ross SA, Watson D, Brown JC (1973) Stimulation of insulin secretion by gastric inhibitory polypeptide in man. $I$ Clin Endocrinol Metab 37: 826-828

38. Iversen $J$ (1973) Effect of acetylcholine on the secretion of glucose and insulin from the isolated perfused canine pancreas. Diabetes 22: $381-387$
39. Ipp E, Dobbs RE, Harris V, Arimura A, Vale W, Unger RH (1977) The effects of gastrin, gastric inhibitory polypeptide, secretin and the octapeptide of cholecystokinin upon immunoreactive somatostatin release by the perfused canine pancreas. J Clin Invest $60: 1216-1219$

40. Unger RH, Ipp E, Schusdziarra V, Orci L (1977) Hypothesis: Physiologic role of pancreatic somatostatin and the contribution of D-cell disorders to diabetes mellitus. Life Sci 20: 2081-2086

41. Peterson RA, Dryburgh JR, Brown JC (1975) The effect of somatostatin on release and insulinotropic action of gastric inhibitory polypeptide. Can J Physiol Pharmacol 53: 1200-1205

42. Schlegel W, Harvey RF, Raptis S, Oliver JM, Pfeiffer EF (1977) Intibition of cholecystokinin-pancreozymin release by somatostatin. Iancet II: 166-168

43. Sakurai H, Dobbs RE, Unger RH (1975) The effect of somatostatin on the response of GLI to the intraduodenal administration of glucose, protein and fat. Diabetologia 11: $427-430$

44. Bloom SR, Ralphs DN, Besser GM, Hall R, Coy DH, Kastin AJ, Schally AV (1975) Effect of somatostatin on motilin levels and gastric emptying. Gut 16: 834

45. Dollinger HC, Raptis S, Goebell H, Pfeiffer EF (1976) Effect of somatostatin on gastrin, insulin, gastric and exocrine pancreatic secretion in man. In: Case $\mathrm{RH}$, Goebell $\mathrm{H}$ (eds) Stimulus-secretion coupling in the gastrointestinal tract. MTP, Lancaster, p 403-405

46. Boden G, Sivitz MC, Owen OE, Essa-Koumar N, Lauder JH (1975) Somatostatin suppresses secretin and pancreatic exocrine secretion. Science 190: 163-165

47. Bloom SR, Mortimer CH, Thorner MO, Besser GM, Hall R, Gomez-Pan A, Roy VM, Russell RCG, Coy DH, Kastin AJ, Schally AV (1974) Inhibition of gastrin and gastric acid secretion by growth homone release inbuting hormone. Lancet II: 1106-1109

48. Creutzfeldt W, Laukisch PG, Folsch UR (1975) Hemmung der Sekretin und Cholezystokinin-Pancreozymin induzierten Saftund Enzymsekretion des Pankreas und der Fallenblasenkontraktion beim Menschen durch Somatostatin. Dtsch Med Wochenschr 100: 1135-1138

49. Schusdziarra V, Ipp E, Harris V, Dobbs RE, Raskin P, Orci L, Unger RH (1978) Studies of the physiology and pathophysiology of the pancreatic D-cell. Metabolism 27 [Suppl 1]: $1227-1232$

50. Gomez-Pan A, Reed ID, Albins M, Shaw B, Hall R; Besser GM, Coy DH, Kastin AJ, Schally AV (1975) Direct inhibition of gastric acid and pepsin secretion by growth hormone release inhibiting hormone (somatostatin) in cats. Lancet I: 888-890

51. Wilson RM, Boden G, Shore LS, Essa-Koumar N (1977) Effect of somatostatin on meal-stimulated pancreatic exocrine secretion in dogs. Diabetes 26: 7-10

52. Schusdziarra V, Harris V, Arimura A, Unger RH (1979) Evidence for a role of splanchnic somatostatin in the homeostasis of ingested nutrients. Endocrinology 104: 1705-1708

53. Schusdziarra V, Zyznar E, Rouiller D, Boden G, Brown J, Arimura A, Unger RH (1980) Splanchnic somatostatin: A hormonal regulator of nutrient homeostasis. Science 207: $530-532$

54. Feyrter $F$ (1963) Uber die peripheren endokrinen (parakrinen) Drüsen des Menschen, 2. Maudrich, Wien Düsseldorf

55. Gilula NB, Reeves OR, Steinbach A (1972) Metabolic coupling, ionic coupling and cell contacts. Nature 235: 262-265

56. Orci L, Unger RH (1975) Hypothesis: Functional subdivision of islets of Langerhans and possible role of D-cells. Lancet II: 1243-1244 
57. Unger RH, Orci L (1977) Hypothesis: The possible role of the pancreatic $\mathrm{D}$-cell in the normal and diabetic states. Diabetes 26: $241-244$

58. Samols E, Marri G, Marks V (1965) Promotion of insulin secretion by glucagon. Lancet II: $415-416$

59. Patton GS, Ipp E, Dobbs RE, Orci L, Vale W, Unger RH (1977) Pancreatic immunoreactive somatostatin release. Proc Natl Acad Sci USA 74: 2140-2143

60. Samols E, Tyler JM, Marks V (1972) Glucagon-insulin interrelationships. In: Lefebvre PJ, Unger RH (eds) Glucagon: Molecular physiology, clinical and therapeutic implications. Pergamon Press, Oxford, p 151-173

61. Koerker DJ, Ruch W, Chideckel E, Palmer J, Goodner CJ, Ensinck J, Gale CC (1974) Somatostatin: Hypothalamic inhibitor of the endocrine pancreas. Science 184: $482-483$

62. Alberti K, Christensen NJ, Hansen A-AP, Lundbaek J, Lundbaek K, Iversen J, Seyer Hansen K, Ørskov H (1973) Inhibition of insulin secretion by somatostatin. Lancet II: 1299-1301

63. Buchanan AD, McCarroll AM (1972) Abnormalities of glucagon metabolism in untreated diabetes mellitus. Lancet II: 1394-1395

64. Orci L, Malaisse-Lagae F, Ravazzola M, Rouiller D, Renold AE, Perrelet A, Unger RH (1975) A morphological basis for intercellular communication between $A-$ and $B$-cells in the endocrine pancreas. J Clin Invest 56: 1066-1070

65. Meda P, Amherdt M, Perrelet A, Orci L (1980) Direct exchange of nucleotides between pancreatic endocrine cells. Diabetes 29 [Suppl 2]: 25 A

66. Bernard C (1859) Leçons au college de France: Du diabète, Clinique européenne

67. Aguilar-Parada E, Eisentraut AM, Unger RH (1969) Pancreatic glucagon secretion in normal and diabetic subjects. Am J Med Sci 257: 415-418

68. Assan.R, Hautecouverture G, Guillemant S, Dauchy F, Protin P, Derot M (1969) Pathol Biol (Paris) 17: 1095-1105

69. Unger RH, Aguilar-Parada E, Muller WA, Eisentraut AM (1970) Studies of pancreatic alpha cell function in normal and diabetic subjects. J Clin Invest 49: 837-848

70. Müller WA, Faloona GR, Aguilar-Parada $E$, Unger RH (1970) Abnormal alpha cell function in diabetes: Response to carbohydrate and protein ingestion. $\mathrm{N}$ Engl J Med 283: 109-115.

71. MüllerWA, Faloona GR, Unger RH (1971) The effect of experimental insulin deficiency on glucagon secretion. $J$ Clin Invest 50: 1992-1999

72. Dobbs RE, Sakurai $H$, Faloona GR, Valverde I, Baetens D, Orci L, Unger RH (1975) Glucagon: Role in the hyperglycemia of diabetes mellitus. Science $187: 544-547$

73. Unger RH, Orci L (1975) Hypothesis: The essential role of glucagon in the pathogenesis of diabetes mellitus. Lancet I: 14-16

74. Unger RH (1978) Role of glucagon in the pathogenesis of diabetes: The status of the controversy. Metabolism 27: 1691-1709

75. Strickland WG, Blackmore PF, Exton JH (1980) The role of calcium in alpha-adrenergic inactivation of glycogen synthase in rat hepatocytes and its inhibition by insulin. Diabetes 29; $617-622$

76. Gerich JE, Lorenzi M, Schneider V, Tsalikian E, Karam JH, Forsham PH (1975) Prevention of human diabetic ketoacidosis by somatostatin. Evidence for an essential role of glucagon. N Engl J Med 292: 985-989

77. Cherrington AD, Lacy WW, Chiasson JL (1978) Effect of glucagon on glucose production during insulin deficiency in the dog. J Clin Invest 62: 664-667

78. Sakurai H, Dobbs RE, Unger RH (1975) The role of glucagon in the pathogenesis of the endogenous hyperglycemia of diabetes mellitus. Metabolism 24: 1287-1297

79. Raskin P, Unger RH (1977) Effects of exogenous hyperglucagonemia in insulin-treated diabetics. Diabetes 26 : 1034-1039

80. Raskin P, Unger RH (1978) Hyperglucagonemia and its suppression: Importance in the metabolic control of diabetes. $\mathrm{N}$ Engl J Med 299; 433-436

81. Pickup JC, Keen H, Viberti GC, White MC, Kohner EM, Parsons JA, Alberti KGMM (1980) Continuous subcutaneous insulin infusion in the treatment of diabetes mellitus. Diabetes Care 3: $290-300$

82. Raskin P, Pietri A, Unger RH (1979) Changes in glucagon levels after four to five weeks of glucoregulation by portable insulin infusion pumps. Diabetes 28: 1033-1035

83. Raskin P, Aydin I, Unger RH (1976) The effect of insulin on the exaggerated glucagon response to arginine stimulation in diabetes mellitus. Diabetes 25: 227-229

84. Raskin P, Aydin I, Yamamoto T, Unger RH (1978) Abnormal alpha cell function in human diabetes: The response of oral protein. Am J Med 64: 988-997

85. Raskin P, Fujita Y, Unger RH (1975) Effect of insulin-glucose infusions on plasma glucagon levels in fasting diabetics and nondiabetics. $\mathrm{J}$ Clin Invest 56: 1132-1138

86. Patel YC, Orci L, Bankier A, Cameron DP (1976) Decreased pancreatic somatostatin (SRIF) concentration in spontaneously diabetic mice. Endocrinology 99: 1415-1418

87. de Goncourt.E, de Goncourt J (1956) Journal, Memoires de la vie litteraire (Monaco) VII, p 192-193

88. Virtanen R (1967) Claude Bernard and the history of ideas. In: Grande F, Visscher MB (eds). Schenkman Publishing Co, Cambridge Mass, p 9-23

89. Olmstead EH (1967) Historical phases in the influence of Bernard's scientific generalizations in England and America. In: Grande F, Visscher MB (eds). Schenkman Publishing Co, Cambridge Mass, p 24-33

Received: September 17, 1980

Dr. R. H. Unger

Veterans Administration Medical Center

5323 Harry Hines Boulevard

Dallas, TX 75235

USA 